\title{
Biochemical and Mineral Alterations of Milk Chemistry in Mastitis
}

\author{
A. Muhee ${ }^{1 *}$, H. U. Malik ${ }^{1}$, I. Asharaf ${ }^{1}$, O. S. Shah ${ }^{1}$, A. Jan ${ }^{1}$, Muheet ${ }^{1}$, \\ W. Rather ${ }^{1}$ and Showkeen Muzamil ${ }^{2}$ \\ ${ }^{1}$ Department of Veterinary Medicine Ethics and Jurisprudence, F.V.Sc \& A.H, \\ SKUAST-K, Srinagar- 192301, Jammu and Kashmir, India \\ ${ }^{2}$ Molecular Biology Lab, Division of Veterinary Biochemistry, Faculty of Veterinary Sciences \& \\ Animal Husbandry, Sheri Kashmir University of Agricultural Science \& Technology-Kashmir \\ (SKUAST-K), Srinagar, J\&K-190006, India \\ *Corresponding author
}

\begin{tabular}{|l|l}
\hline \multicolumn{1}{c}{ A B S T R A C T } \\
\cline { 2 - 3 } \multicolumn{1}{l|}{$\begin{array}{l}\text { Keywords } \\
\begin{array}{l}\text { Biochemical, } \\
\text { mineral alterations, } \\
\text { milk chemistry }\end{array}\end{array}$} & $\begin{array}{l}\text { The study was undertaken on clinical cases of bovine mastitis presented to } \\
\text { Teaching Veterinary Clinical Complex (TVCC), F.V.Sc \& A.H, SKUAST- } \\
\text { K and its adjoining areas from August 2014-May 2016. Animals were } \\
\text { divided into two groups, groups A comprised of animals with clinical } \\
\text { mastitis and animals in group B comprised of normal healthy animals } \\
\text { which served as control. In present study mean values of lactose, fat, } \\
\text { casein, copper, selenium, zinc magnesium and SNF were significantly } \\
\text { decreased in animals with mastitis. Mastitis is characterised by change in } \\
\text { Accepted: } \\
\begin{array}{l}\text { 30 June 2017 } \\
\text { 10 Juilable Online: } 2017\end{array}\end{array}$ \\
\hline \hline
\end{tabular}

\section{Introduction}

Mastitis is characterized by a range of physical and chemical changes of milk and pathological changes in udder tissues. It is recognized as number one problem in dairy animals which results in great economic losses to the farmers due to reduced productivity and cost of treatment (Auldist and Hubble., 1998). So far, conventional antibiotic therapy is the only proven method for the prevention and control of mastitis, but several problems arise from the use of antibiotics like developing resistance to antibiotic, questionable drug efficacy and presence of antibiotic residues in the milk (Auldist and Hubble., 1998). In the dairy cattle population, both clinical and subclinical mastitis can affect the composition and manufacturing properties of milk (Pyorala, 2003).

There are various factors that contribute to variations in milk composition like the stage of lactation of the cows, breed, plane of nutrition, seasonal factors and pathological changes associated with mastitis (Auldist and Hubble, 1998; Auldist, et al., 1995). These 
facts highlight the need for completely newer moieties for treatment of mastitis. In present study, changes in milk composition associated with mastitis and an attempt to their restoration through supplementation of antioxidant trace- mineral mixture is made.

\section{Materials and Methods}

In present study a total of 39 multiparous cows in the age group of 4-8 years with BCS 3.0 were included. The study was undertaken on clinical cases of bovine mastitis presented to Teaching Veterinary Clinical Complex (TVCC), F.V.Sc \& A.H, SKUAST-K and animal from local animal husbandry dispensaries in Ganderbal, Manasbal, Shuhama, Gulab bagh and Shalimar from August 2014-May 2016. Out of 39 animals 27 animals were found to be affected with clinical mastitis.

Animals were divided into two groups, groups A comprised of animals with clinical mastitis and animals in group B comprised of normal healthy animals which served as control Trace mineral status for copper, zinc, manganese and selenium were estimated by AAS. The constituents of milk like lactose $(\%)$, fat $(\%)$, casein (\%), SNF (\%) were estimated using milk analyser (Speedy Lab, Model 4828, Astori tecnica, Italy).

\section{Results and Discussion}

In present study mean values of lactose, fat, casein and SNF are presented in Tables 1 and Table 2. Mastitis results in decrease in synthesis increase in permeability of milk barrier and an increase in the proteolytic/enzymatic activities in milk (Holdaway, 1990 and Roux, 2003). The values of lactose $(\%)$ in mastitic group were significantly lower than the mean values the normal control group. Our findings of decrease in the concentration of milk lactose are in agreement with Auldist et al., (1995); Nguyen and Neville (1998); Pyorala (2003), Bruckmaier et al., (2004) and Bansal et al., (2005).

Furthermore, according to Auldist et al., (1995), many of the common mastitis-causing organisms are capable of fermenting lactose. The mean values of casein $(\%)$ in mastitic group were significantly lower than normal control group. Our findings are in agreement with Auldist and Hubble (1998) who reported that the decrease in casein concentrations during mastitis is largely due to post-secretory degradation of casein by proteinases originating from mastitis-causing organisms, leucocytes or the blood and in part to a reduction in the synthesis and secretion of casein as a result of physical damage to the mammary epithelial cells by microbial toxins during mastitis.

The values for fat were lower in mastitic animals as compared to the healthy control group. Our findings are in agreement with Holdaway (1990), Auldist (1995) and Auldist and Hubble (1998). Holdaway (1990) stated that in clinical mastitis the fat content decreases because of the lower volume of milk. In addition, the leakage of lactose from the milk takes with it water and the volume of secretion left in the gland decreases.

Our findings of decreased SNF content of milk in clinical mastitis are in agreement with Bansal et al., (2005) and Reis et al., (2013) who also reported a decrease in SNF content of milk in mastitis. The decrease in SNF content of milk in mastitis is attributed to changes in vascular permeability due to the inflammatory process and the damage of epithelial cells responsible for the synthesis of milk components as well as changes in the enzymatic action of somatic cells or microorganisms in the infected mammary gland (Dobrasnié et al., 2008). 
Table.1 Effect of mastitis on milk chemistry in mastitic animals

\begin{tabular}{|c|c|c|}
\hline Parameters & Control Group & Mastitic Group \\
\hline Lactose (\%) & $4.34 \pm 0.10^{\mathrm{a}}$ & $3.52 \pm 0.06^{b}$ \\
\hline Casein $(\%)$ & $2.76 \pm 0.11^{\mathrm{a}}$ & $2.06 \pm 0.04^{b}$ \\
\hline Fat $(\%)$ & $4.20 \pm 0.13^{\mathrm{a}}$ & $2.96 \pm 0.06^{b}$ \\
\hline SNF (\%) & $7.99 \pm 0.14^{\mathrm{a}}$ & $7.15 \pm 0.02^{b}$ \\
\hline
\end{tabular}

Values within a row having superscript $(\mathrm{a}, \mathrm{b})$ with atleast one common alphabet do not differ significantly at $5 \%$ level $(\mathrm{p}<0.05)$ from each other.

Table.2 Comparison of trace mineral profile between healthy lactating (control group) and mastitic animals

\begin{tabular}{|c|c|c|}
\hline Parameters & Control Group & Mastitic Group \\
\hline Copper $(\mu \mathrm{mol} / \mathrm{L})$ & $8.25 \pm .07^{\mathrm{a}}$ & $7.01 \pm 0.06^{b}$ \\
\hline Zinc $(\mu \mathrm{mol} / \mathrm{L})$ & $14.47 \pm .31^{\mathrm{a}}$ & $11.71 \pm 0.16^{b}$ \\
\hline Mn $(\mu \mathrm{mol} / \mathrm{L})$ & $3.78 \pm .11^{\mathrm{a}}$ & $2.94 \pm 0.04^{b}$ \\
\hline Se (ng/mL) & $38.47 \pm 1.67^{\mathrm{a}}$ & $31.29 \pm 1.14^{b}$ \\
\hline
\end{tabular}

Values within a row having superscript $(a, b, c)$ with atleast one common alphabet do not differ significantly at $5 \%$ level $(\mathrm{p}<0.05)$ from each other.

In the present study the values of copper were low in mastitic animals as compared to healthy control group. Our findings are in agreement with Kleczkowski, 2008 who also found decreased concentrations of copper in animals with clinical mastitis. The present study revealed decreased levels of $\mathrm{Mn}$ in clinical mastitis as compared to normal control group. Our findings of decreased values of $\mathrm{Mn}$ in clinical mastitis are in agreement with Erskine et al., 1997 and Yang and $\mathrm{Li}$, (2015) who also reported that the plasmatic levels of minerals decrease in clinical mastitis. Copper is an important cofactor of superoxide dismutase, an enzyme, which protects cells from the pro-oxidative influence of free radicals (Kleczkowski, 2003). The mean values of $\mathrm{Zn}(\mu \mathrm{mol} / \mathrm{L})$ and $\mathrm{Se}(\mathrm{ng} / \mathrm{mL})$ for normal healthy control group and the mastitic group (Table 4). In our study, the zinc levels in dairy cows with clinical mastitis were low compared with healthy cows. Ibrahim et al., 2016 also found a significant decrease in the values of zinc in cows with clinical mastitis. The present study revealed decreased levels of $\mathrm{Se}$ in clinical mastitis as compared to normal control group. The present study findings of low Se values in clinical mastitis are in agreement with Weiss et al., (1990), Erskine et al., (1987), Grasso et al., (1990) and Kommisrud et al., (2005). Selenium is an essential micronutrient present in tissues throughout the body and is important physiologically because it is an integral component of the enzyme glutathione peroxidase (Diplock, 1981). Weiss et al., (1990), found that high serum Se concentrations are associated with reduced rates of clinical mastitis and low bulk tank milk SCC. Mastitis is characterised by change in the milk chemistry as evidenced by the present study. So therapeutic regime should be designed to address the changes in milk chemistry in mastitis.

\section{References}

Auldist, M.J., Coats, S., Rogers, G.L., and McDowell, G.H., Changes in the composition of milk from healthy and mastitic dairy cows during the lactation 
cycle. Australian Journal of Experimental Agriculture, 1995. 35: p. 427-436.

Auldist, M.J., Hubble, I.B., Effects of mastitis on raw milk and dairy products. The Australian Journal of Dairy Technology, 1998. 53: p. 28-36.

Bansal, B.K., Hamann, J., Grabowski, N. andSingh, K.B. 2005. Variation in the composition of selected milk fraction samples from healthy and mastitis quarters, and its significance for mastitis diagnosis. Journal ofDairy Research72:144-152.

Bruckmaier, M, Ontsouka, E. andBlum, W. (2004).Fractionized milk composition in dairy cows with subclinical mastitis. Veterinary medicine-Czech 8:283-290.

Erskine, R.J., Eberhar, R.J. and Hutchinson, L.J. 1987. Blood selenium concentrations and glutathione peroxidase activities in dairy herds with high and low somatic cell counts. Journal of the American Veterinary Medical Association 11: 1417-1421.

Gaafar, H.M.A., Basiuoni, M.I., Ali, M.F.E., Shitta, A.A. andShamas, A.S.E. 2010. Effect of zinc methionine supplementation on somatic cell count in milk and mastitis in Friesian cows. Archiva Zootechnica13: 36-46.

Grasso, P. J., Scholz, R. W., Erskine,, R. J. and Eberhart, R. J. 1990. Phagocytosis, bactericidal activity, and oxidative metabolism of milk neutrophils from dairy cows fed selenium-supplemented and selenium-deficient diets. American Journal of Veterinary Research 51:269-274.

Holdaway, R.J. 1990.A comparison of methods for the diagnosis of bovine subclinical mastitis within New Zealand dairy herds. Thesis (Ph. D.)submitted to Massey University.

Kleczkowski M., Klucinski W., Sitarska E.,
Sikora J., Kasztelan R. 2003.Influence of mineral nutrition on superoxide dismutase activity in blood of cows. Bulletin of the Veterinary Institute in Pulawy 47 :547-554.

Kleczkowski, M., Kluciński, W.Z., Jakubowski, T., Fabisiak1, M. and Dembele, K. 2008. Copper status and SOD activity in blood of cows affected with clinical mastitis. Bulletin of the Veterinary Institute in Pulawy 52:387-390.

Kommisrud, E., Østerås, O. and Vatn, T. 2005. Blood Selenium Associated with Health and Fertility in Norwegian Dairy Herds. Acta Veterinaria Scandinavica46:229-240.

Nguyen, A. D. and Neville, M. C. 1998. Tight junction regulation in the mammary gland. Journal of Mammary Gland Biology and Neoplasia3(3): 233-246.

Pyorala, S., Indicators of inflammation in the diagnosis of mastitis. Veterinary Research, 2003. 34(5): p. 565-578.

Reis, C.B.M., Barreiro, J.R., Porcionato, M.A.F. andSantos, M.V.D. 2013. Effect of somatic cell count and mastitis pathogens on milk composition in Gyr cows. VeterinaryResearch9(67) : 148-163.

Roux, Y.I., Laurent, F. and Moussaoui, F. 2003.Polymorphonuclear proteolytic activity and milk composition change. Veterinary Research34(5):629-645.

Weiss, W.P., Hogan, J.S. and Smith, K.L.1990. Relationships among selenium, vitamin Eand mammary gland health in commercial dairy herds. Journal of Dairy Science 73:381.

Yang, F. L.and Li, X. S. 2015.Role of antioxidant vitamins and trace elements in mastitis in dairy cows. Journal of Advanced Veterinary Animal Research2 (1): 1-9.

\section{How to cite this article:}

Muhee A., H. U. Malik, I. Asharaf, O. S. Shah, A. Jan, Muheet, W. Rather and Showkeen Muzamil. 2017. Biochemical and Mineral Alterations of Milk Chemistry in Mastitis. Int.J.Curr.Microbiol.App.Sci. 6(7): 4591-4594. doi: https://doi.org/10.20546/ijcmas.2017.607.480 